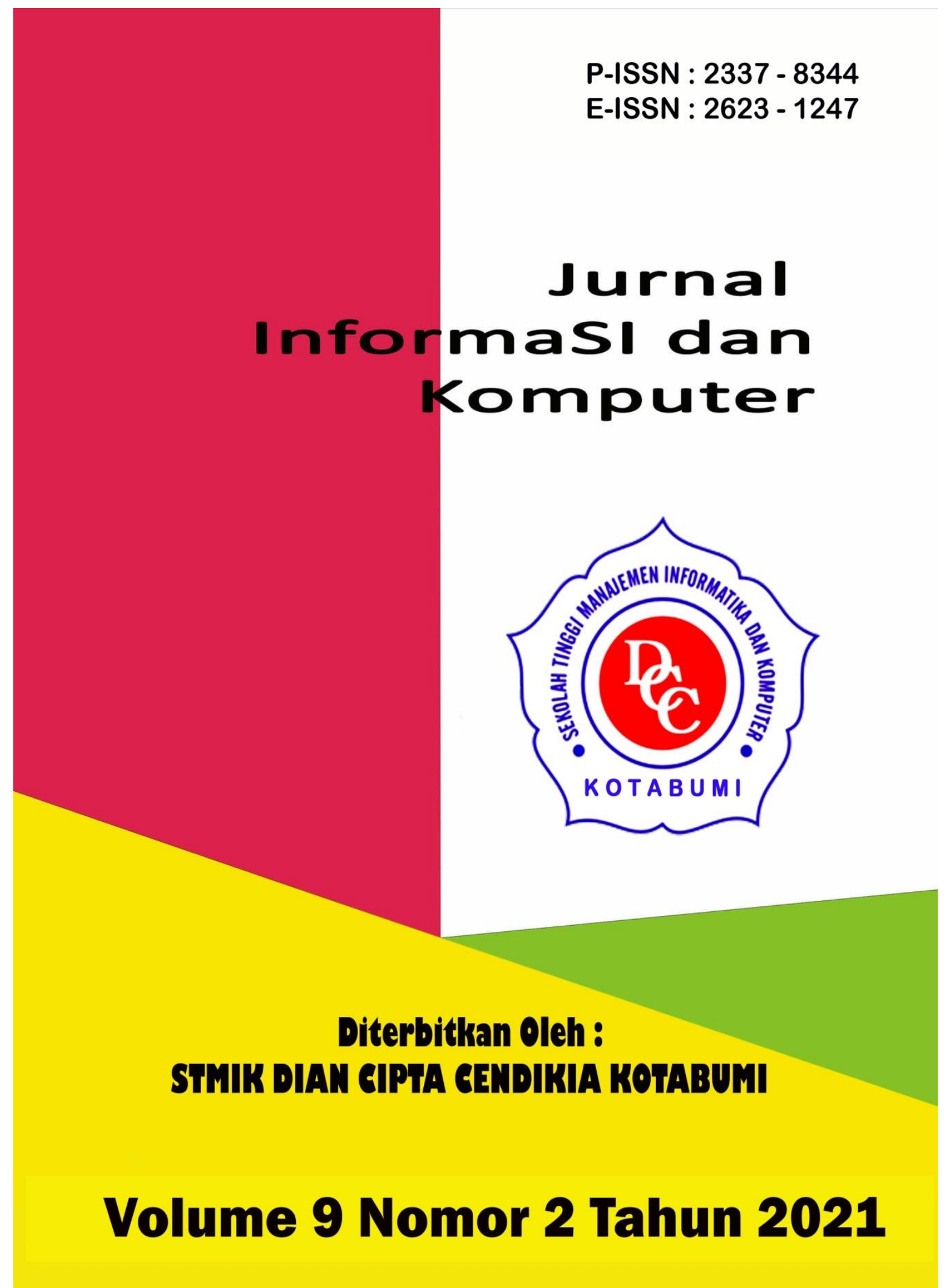




\section{Penerbit}

\section{Lembaga Penelitian STMIK Dian Cipta Cendikia Kotabumi}

Hak atas naskahh/tulisan tetap berada pada penulis, isi diluar tangung jawab penerbit dan Dewan Penyunting 


\section{PENGANTAR REDAKSI}

Puji syukur dipanjatkan kehadirat Tuhan Yang Maha Esa, atas karunia dan limpahan rahmatNYA jualah Jurnal Informasi dan komputer (JIK) STMIK Dian Cipta Cendikia Kotabumi ini dapat terwujud.Jurnal Informasi dan Komputer (JIK) yang terbit dua (2) kali dalam setahun ini merupakan suatu wadah untuk penyebar luasan hasil-hasil penelitian, studi pustaka, karya ilmiah yang berkaitan dengan Informasi dan Komputer khususnya bagi dosen-dosen STMIK Dian Cipta Cendikia Kotabumi serta umumnya para cendikiawan, praktisi, peneliti ilmu Informatika dan Komputer.

Harapan, dengan diterbitkannya Jurnal Informasi dan Komputer (JIK) ini sebagai salah satu bentuk sumbangan pemikiran dalam pengembangan ilmu informatika dan komputer yang berkaitan dengan kajian-kajian di bidang tekhnologi Informatik, Komunikasi Data dan Jaringan Komputer, perancangan dan Rekayasa Perangkat Lunak, serta ilmu-ilmu yang terkait dengan bidang Informasi dan Komputer lainnya.

Berkenaan dengan harapan tersebut, kepada para peneliti, dosen dan praktisi yang memiliki hasil-hasil penelitian, kajian pustaka, karya ilmiah dalam bidang tersebut diatas, dengan bangga redaksi Jurnal Informasi dan Komputer (JIK) menerima naskah ringkasan untuk dimuat pada jurnal Informasi dan Komputer (JIK) STMIK Dian Cipta Cendikia Kotabumi dengan berpedoman pada penulisan naskah jurnal sebagaimana dilampirkan pada halaman belakang (Bagian kulit dalam) buku jurnal ini.

Mutu dari suatu jurnal ilmiah tidak hanya ditentukan oleh para pengelolanya saja, tetapi para penulis dan pembaca jualah yang mempunyai peranan besar dalam meningkatkan mutu jurnal Informatika dan Komputer ini. Merujuk pada realita ini kamu sangat mengharapkan peran aktif dari peneliti untuk bersama-sama menjaga dan memelihara keberlangsungan dari jurnal Informasi dan Komputer STMIK Dian Cipta Cendikia Kotabumi ini. Yang juga tidak kalah pentingnya dari partisipasi tersebut diatas, adalah saran dan kritik yang membangun dari pembaca yang budiman agar kiranya dapat disampaikan langsung kepada redaksi JIK. Saran dan kritik yang membangun akan dijadikan masukan dan pertimbangan yang sangat berarti guna peningkatan mutu dan kualitas Jurnal Informasi dan Komputer STMIK Dian Cipta Cendikia Kotabumi.

Tak lupa diucapkan terima kasih yang tak terhingga atas perhatian dan kerjasama dari semua pihak yang tak dapat disebutkan satu persatu hingga dapat diterbitkan nya Jurnal Informasi dan Komputer (JIK) STMIK Dian Cipta Cendikia Kotabumi. Semoga apa yang telah diperbuat untuk kebaikan akan menjadi amal ibadah, amin.

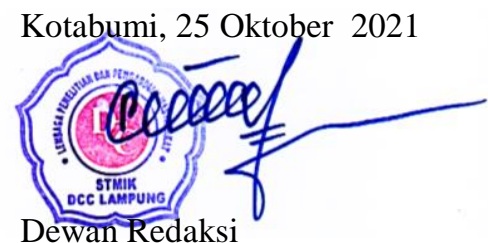




\section{JURNAL INFORMASI DAN KOMPUTER}

Volume 9 Nomor 2 Oktober 2021

Jurnal Informasi dan Komputer merupakan Sarana informasi ilmu pengetahuan, Tekhnologi dan Komunikasi yang berupa hasil penelitian, tulisan ilmiah, Ataupun studi pustaka. Jurnal ini terbit dua kali setahun pada bulan April dan Oktober. Berisi hasil penelitian ilmiah di bidang informatika yang bertujuan untuk menghubungkan adanya kesenjangan antar kemajuan teknologi dan hasil penelitian. Jurnal ini di terbitkan pertama kali pada tahun 2013.

Penanggung Jawab:

Ketua STMIK Dian Cipta Cendikia Kotabumi

\section{Pembina:}

Ketua STMIK Dian Cipta Cendikia Kotabumi Ketua Lembaga Penelitian STMIK Dian Cipta Cendikia Kotabumi

\section{Pimpinan Redaksi}

Dwi Marisa Efendi,.S.Kom.,M.Ti

\section{Redaksi pelaksana}

Rustam,.S.Kom,.M.Ti (STMIK Dian Cipta Cendikia Kotabumi)

Nurmayanti M.Kom (STMIK Dian Cipta Cendikia Kotabumi)

Sukatmi,.S.Kom., M.Kom (AMIK DCC Bandar Lampung)

Sampurna Dadi Riskiono,M.Kom (Universitas Teknokrat Indonesia)

Ifo Wahyu Pratama,S.Kom.,M.Ti(AMIK MASTER Lampung)

\section{Mitra Bestari}

Dr. RZ. ABDUL AZIZ, ST., MT (Institut Informatika dan Bisnis Darmajaya)

Dr. Dadang Sudrajat, S.Si, M.Kom (STMIK IKMI Cirebon)

Dr. Septafiansyah Dwi Putra, S.T., M.T (Politeknik Negeri Lampung)

Dr. Evi Grativiani, S.E., M.S.I (Universitas Sebelas Maret)

Rohmat Indra Borman ( Universitas Teknokrat Indonesia )

Ferry Wongso, S.KOm., M.Kom ( STMIK Darma Pala Riau)

Ferly Ardhy, S.Kom., M.Ti ( Universitas Aisyah Pringsewu )

Firmansyah, S.E., M.Si (STMIK Darma Pala Riau)
Amarudin (Universitas Teknokrat Indonesia)

Didi Susianto, S.T., M.Kom (AMIK Dian Cipta Cendika Bandar Lampung)

Alhibarsyah, St., M.Kom (STMIK Tunas

Bangsa Bandar Lampung)

Kemal Farouq Mauladi, S.Kom .M.Kom (Universitas Islam Lamongan)

Rima Mawarni, M.Kom ( STMIK Dian Cipta Cendikia Kotabumi)

Wira Jaya Hartono, S.Pd., M.Pd ( STMIK Darma Pala Riau)

Penerbit : STMIK Dian Cipta Cendikia Kotabumi Bekerja Sama Dengan LPPM STMIK Dian Cipta Cendikia Kotabumi.

\section{Alamat Redaksi/Penerbit:}

Jl. Negara No. 3 Candimas Kotabumi Lampung Utara

No Telpon/Fax 072423003

Email : 1ppm-stmik@dcc.ac.id 


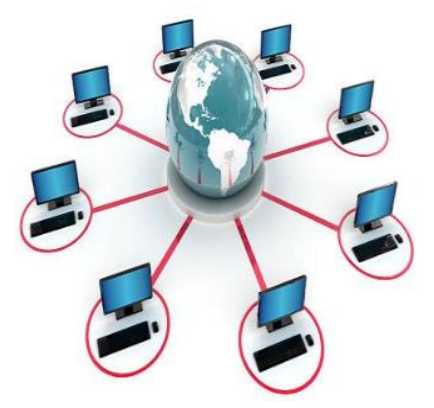

\section{JURNAL INFORMASI DAN KOMPUTER VOL. 9 NO. 2 THN. 2021}

\section{DAFTAR ISI}

Halaman

Sistem Informasi Akuntansi Persedian Barang Berbasis Web Pada Lembaga

Permasyarakatan Kelas II A Banceuy Bandung : "Kelompok Tani Desa Banjar Kertarahayu" Teuku Rian Hardiyansyah, Fatia Salsa Azzahra (Politeknik Piksi Ganesha Bandung ${ }^{1,2}$ ).

Penerapan Finite State Automata Pada Vending Machine Penjual Obat Non Resep

Dokter Dan Keperluan Medis

Eko Supriyanto $^{1}$, Angga Ardiansyah ${ }^{2}$, Frieyadie $^{3}$, Sri Rahayu ${ }^{4}$, Windu Gata ${ }^{5}$

(Universitas Nusa Mandiri ${ }^{12}$ )

Sistem Pendukung Keputusan Untuk Menentukan Kelayakan Pengajuan Sertifikasi Guru Dengan Metode Simple Additive Weighting (Studi Kasus : Ma Al Muhajirin Janti Jogoroto Jombang)

Budiman, umam baharudin, winarti

(Universitas Darul 'Ulum Jombang)

Perancangan Infrastruktur Domain Name Server Lokal Menggunakan Ubuntu Server 16.04

Pada PT. Xyz

Zaenal Mutaqin Subekti, Hendra Setiawan, Satria, Widia Murni Wijaya,

Aliy Hafiz, Warsudi

(STMIK Bani Saleh, Universitas Negeri Yogyakarta, AMIK Dian Cipta Cendikia,

STMIK MIC CIkarang)

Perancangan Sistem Informasi Idea Proposal (Ip) Berbasis Web Pada Pt. Paxel Algorita Unggul

Julian Murhan Sahputra, Indah Purnamasari

(Universitas Nusa Mandiri ${ }^{12}$ )

Sistem Pendukung Keputusan Untuk Menentukan Ekstrakurikuler Atletik

Berdasarkan Bakat Siswa Menggunakan Metode Profile Matching

Agnes Basuki, Petrus Sokibi, Tiara Eka Putri

(Universitas Catur Insan Cendekia)

Penerapan Algoritma K-Means Untuk Pengelompokan Usia Calon Penerima Vaksin

Di Kab. Ngawi

Irna Yuniarfi, Saifulloh

(Universitas PGRI Madiun ${ }^{12}$ )

System Penilaian Seleksi Calon Karyawan Baru Menggunakan Metode Simple Additive Weighting (SAW) Di PT.TNA

Anik Sri Wahyuningsih, Yudhi Firmansyah

(Universitas Panca Sakti Bekasi ) 
Perancangan Sistem Informasi Pembayaran SPP Menggunakan Framework Laravel Ichwan Habib Moudi

(Universitas Panca Sakti Bekasi)

Implementasi Algoritma K-Means Dan Algoritma Apriori Optimasi Kinerja Ecu

(Study Kasus Mobil Avanza Dan Xenia)

Sigit Mintoro' Asep Afandi

(STMIK Dian Cipta Cendikia Kotabumi)

Sistem Pakar Penyakit Buah Kakao Untuk Peningkatan Hasil Panen Kakao Menggunakan

Metode Case Base Reasoning (CBR) Berbasis Web Mobile

Aliy hafiz, Verawati

(AMIK Dian Cipta Cendikia,Bandar Lampung)

Penerapan Metode Rapid Application Develomment (RAD) Dalam Pengembangan

Sistem Pemesanan Menu Berbasis Android

Aris Baihaqi, Tumini

(Fakultas Sains dan Teknologi ${ }^{1,2}$ )

Rancang Bangun Sistem Informasi Geografis Pariwisata Di Lampung Timur

Sukatmi, Rexa Alfa Rizi

(AMIK DCC Bandar Lampung ${ }^{12}$ )

Implementasi Psak No. 45 Pada Proses Penyusunan Laporan Keuangan Menggunakan

M.S. Excel Dan Aplikasi Accurate Accouting Pada STMIK Bani Saleh

Marhakim, Willy Adam

(STMIK Bani Saleh ${ }^{12}$ )

Sistem Prediksi Harga KOPI LAMBAR ( Lampung Barat) Dengan Metode

Backpropagation, dan Double Exponential ( Studi Kasus BUMDES )

Supriyanto, Dwi marisa Efendi,Rhomadhon

(STMIK Dian Cipta cendikia Kotabumi ${ }^{1-}$ )

Sistem Informasi Pemasaran Produk Umkm Berbasis Web Pada Kecamatan Bumi

Nabung Lampung Tengah

Yuli Syafitri, Agus Prasetyo, Reni Astika

(AMIK Dian Cipta Cendikia Bandar Lampung)

Rancang Bangun Aplikasi Pembelajaran Aksara Lampung Berbasis Android

Ferly Ardhy, Hendra Syahrobi

(Universitas Aisyah Pringewu ${ }^{1,}$ STMIK Dian Cipta Cendikia ${ }^{2}$ )

Sistem Pakar Diagnosa Penyakit Kulit Pada Balita Menggunakan Metode Naïve

Bayes Dan Forward Chaining Studi Kasus Puskesmas Cempaka Sungkai Selatan

Sidik Rahmatullah, Rima Mawarni

(STMIK Dian Cipta Cendikia Kotabumi ${ }^{12}$ )

Rekayasa Perangkat Lunak Perhitungan Harga Pokok Produksi Metode

Full Costing Pada Umkm Mitra Cake Di Bandar Lampung

Pitrawati, Arif Sanjaya

(AMIK Dian Cipta Cendikia, Bandar Lampung) 
Rancang Bangun Sistem Ujian Online Menggunakan Algoritma Cosine Similarity

Berbasis Web

Haryono, Zaenal Mutaqin Subekti, Widiyawati, Hidayatullah

(STMIK Bani Saleh ${ }^{1234}$ )

Model Aplikasi Helpdesk Ticketing System Berbasis Web Menggunakan Metode Rad

Indra Permana

Pattern Recognition Tulisan Tangan Huruf Hijaiyah Menggunakan Metode

Convolutional Neural Network (CNN)

Mufassiril Abror, Nopiyanto

(Universitas Panca Sakti Bekasi ${ }^{12}$ )

Aplikasi Sistem Informasi Keuangan Berbasis Android Di Perumahan Taman

Karang Bahagia

Melda Ayulestari

(Universitas Panca Sakti Bekasi)

Audit Pelayanan Sistem Rujukan Online Puskesmas Menggunakan Framework COBIT 5.0

Nurmayanti, Merri Parida, Ngajiyanto, Ina Anzalna

(STMIK Dian Cipta Cendikia Kotabumi ${ }^{1234}$ )

Perancangan Sistem Informasi Pengolahan Data Nilai Siswa Berbasis Web

Erin Ermawati, Anik Sri Wahyuningsih

(Fakultas Sain dan Teknologi, Universitas Panca Sakti Bekasi ${ }^{12}$ )

Pengembangan Sistem Pelaporan Data Hasil Inspeksi Barang Berbasis Web

Siska Putriani

(Universitas Pancasakti Bekasi)

Penerapan Extreme Programming Dalam Perancangan Aplikasi Web Food Market

Tumini, Hilman Septiana

(Fakultas Sains dan Teknologi Universitas Panca Sakti Bekasi ${ }^{1,2}$ )

Sistem Pencarian Barang Berbasis Website Menggunakan Php Dan Mysql

Studi Kasus PT. Surya Technology Industri Sulaeman

(Universitas Panca Sakti Bekasi)

Implementasi Metode Prototype Pada Sistem Peminjaman Alat Kerja Berbasis Web

Di PT SK Metalindo

Ali Mulyanto, Arjun Gunawan

(Univeritas Panca Sakti Bekasi)

Aplikasi Tata Cara Wudhu Menggunakan Teknologi Augmented Reality

Sebagai Media Pembelajaran Di TK Al Fatih

Ahmad Yakub , Idarul Fadli

(Universitas Panca Sakti Bekasi ${ }^{12}$ )

Sistem Pakar Diagnosa Penyakit Ayam Petelur Menggunakan Metode Certainty Factor

Berbasis Web Mochammad

Taufiq Hidayat, Ali Mulyanto

(Universitas Panca Sakti Bekasi ${ }^{12}$ ) 
Penerapan Metode Prototyping Dalam Perhitungan Hasil Produksi Menggunakan

Arduino Uno R3 Dan Php Di PT. Indonesia Epson Industry

Amandha Aulia, Ajar Rohmanu

(Universitas Panca Sakti Bekasi ${ }^{12}$ )

System Pendukung Keputusan Penentuan Guru Teladan Dengan Metode Profile Matching

Hasbulloh, Agmawarnida

(Universitas Panca Sakti Bekasi ${ }^{1,2}$ )

Implementasi Waterfall Method Pada Aplikasi Buku Induk Siswa Berbasis Web

Idam Holid, Yogie Krisnayadi

(Universitas Panca Sakti ${ }^{12}$ )

Pengembangan Text To Speech Media Pembelajaran Untuk Pengenalan

Anggota Tubuh Manusia Kelas V Sekolah Dasar

Juwanda Saputra, Ali Mulianto

(Teknik Infomratika Fakulutas Sains dan Teknologi ${ }^{12}$ )

Perancangan Sistem Peminjaman Barang Berupa Aset Tetap Berbasis Web

Pada Lembaga Permasyarakatan Kelas II A Banceuy Bandung

Guntur Salasa Priambodo, Perwito, Candra Mecca Sufyana

(Politeknik Piksi Ganesha Bandung ${ }^{1,2,3}$ )

Metode Pemilihan Karyawan Terbaik Sebagai Penentu Goodwill Perguruan Tinggi

Dengan Menggunakan Metode Topsis (Studi Kasus Perguruan Tinggi Di Lampung Utara)

Dwi Sartika, Pakarti Riswanto

(STMIK Dian Cipta Cendikia Kotabumi)

Sistem Pendukung Keputusan Pemilihan Merek Smartphone Menggunakan

Metode Analytical Hierarchy Process (AHP)

Ade Kiki Fatmawati, Muhammad Sultan Raflie, Norma Yunita

(Universitas Nusa Mandiri ${ }^{123}$ )

Pattern Recognition Aksara Lampung Menggunakan Algoritma Neural Network

Metode Analytical Hierarchy Process (AHP)

Nopiyanto, Rahmadi

(Universitas Panca Sakti Bekasi) 


\title{
RANCANG BANGUN SISTEM UJIAN ONLINE MENGGUNAKAN ALGORITMA COSINE SIMILARITY BERBASIS WEB
}

\author{
Haryono ${ }^{1}$, Zaenal Mutaqin Subekti ${ }^{2}$, Widiyawati ${ }^{3}$, Hidayatullah ${ }^{4}$ \\ STMIK Bani Saleh ${ }^{1234}$ \\ Jl. M Hasibuan No. 68 Bekasi \\ E-mail : haryono.siradku@gmail.com ${ }^{1}$, zms.stmikbanisaleh@gmail.com² ${ }^{2}$,widiyawati.zul@gmail.com³ \\ abilcrew03@gmail.com ${ }^{4}$
}

\begin{abstract}
ABSTRAK
Ujian Online merupakan suatu cara yang digunakan untuk mengevaluasi hasil belajar siswa dalam mengukur taraf pencapaian siswa sebagai peserta didik, sehingga siswa dapat mengetahui batas kemampuan dirinya dalam memahami bidang studi yang ditempuh selama mengikuti pendidikan dengan pelaksanaan ujian menggunakan internet. Rancang bangun sistem ujian online menggunakan algoritma cosine similarity yaitu melakukan perkalian skalar antara query dengan dokumen kemudian dijumlahkan, setelah itu melakukan perkalian antara panjang dokumen dengan panjang query yang telah dikuadratkan, setelah itu di hitung akar pangkat dua. Selanjutnya hasil perkalian skalar tersebut di bagi dengan hasil perkalian panjang dokumen dan query, hasil rancangan sistem ini dapat mempermudah proses pendataan ujian sekolah yang sistematis dan terkomputerisasi, dan dengan adanya sistem ujian sekolah ini dapat mengurangi penumpukan kertas. Rancangan sistem ujian onlie menggunakan use case, diagram activity, class diagram dan rancangan database. Pengujian menggunakan metode black box untuk menguji Interface sistem ujian, Pengujian fungsi dasar sistem, pengujian form handle sistem, dan pengujian keamanan sistem aplikasi.
\end{abstract}

Kata kunci : ujian online, cosine, similarity

\section{ABSTRACTS}

Online exam is a method used to develop student learning outcomes in measuring the quality of students as students, students can know the limits of their abilities in understanding the studies achieved during learning using the internet. Design and build an online exam system using the cosine equation, which is to do a scalar multiplication between the query and the document then add it up, after multiplying the length of the document with the length of the query that has been squared, after calculating the square root. Furthermore, the scalar results are divided by the results of extended documents and queries, the results of this system design can facilitate the systematic and computerized process of collecting school exam data, and with the existence of this school exam system it can reduce paper. The online exam system design uses use cases, activity diagrams, class diagrams and database designs. The test uses the black box method to test the test system interface, test basic system functions, test form handle systems, and test application security systems.

Keywords: online test, cosine, similarity.

\section{PENDAhuluan}

Teknologi Informasi berkembang dengan cepat, begitu juga dengan aplikasi[1] atau sistem informasi yang digunakan untuk kebutuhan pada sekolah menengah. Ujian Online berbasis web[2] merupakan suatu cara yang digunakan untuk mengevaluasi hasil belajar siswa dalam mengukur taraf pencapaian siswa sebagai peserta didik, sehingga siswa dapat mengetahui batas kemampuan dirinya dalam memahami bidang studi yang ditempuh selama mengikuti pendidikan[3] dengan pelaksanaan ujian menggunakan internet, dimana siswa maupun guru tidak harus bertatap muka saat pelaksanaan ujian. Seiring dengan berkembangnya kemajuan teknologi 
informasi[4], mungkin akan sangat terbantu dengan adanya internet. Dengan internet, kita akan mudah menghadirkan layanan yang dapat diakses dari manapun dan kapanpun untuk dapat melakukan pengaksesan informasi[5] didunia ini. Dalam melakukan ujian pada suatu sekolah masih menggunakan manual[6] yaitu dengan menggunakan kertas untuk soal dan untuk pengisian jawaban, sehingga menjadi banyak nya kertas yang digunakan, guru juga sering mengalami kesulitan dalam menyajikan soal-soal ujian yang akan diberikan kepada murid-muridnya, begitu juga dalam melakukan sistem pengolahan nilai yang dilakukan oleh seorang guru dalam melihat hasil ujian muridmuridnya. untuk menunjang kinerja dalam ujian online serta membuat laporan[7] bulanan dibutuhkan sebuah sistem atau aplikasi ujian online berbasis web dengan menggunakan algoritma yang digunakan adalah Cosine Similarity[8], algoritma ini dipilih karena pembangunan sistem yang lebih cepat dan sangat fleksibel dengan perubahan yang terjadi dengan proses pembangunan perangkat lunak.

Seperti yang sudah dilakukan oleh mohammad agus salim dan yeni anis tyasari dengan judul pengembangan aplikasi penilaian[9] ujian essay berbasis online menggunakan algoritma nazief dan adriani dengan metode cosine similarity, tidak ada perbedaan yang signifikan antara hasil koreksi aplikasi penilaian ujian essay berbasis online menggunakan algoritma nazief dan adriani dengan metode cosine similarity dan metode koreksi secara manual[10].

Rancang bangun sistem cerdas pemberian nilai otomatis untuk ujian essai menggunakan algoritma cosine similarity oleh hamdan arfandy dan izmy alwiyah musdar, tujuan pada penelitian ini mengambangkan sebuah sistem ujian berbasis komputer dimana pada sistem ujian essai diberi nilai secara otomatis dengan memanfaatkan metode cosine similarity[11].

\section{METODE PENELITIAN}

Dalam menghitung cosine similarity, pertama yang di lakukan yaitu melakukan perkalian skalar antara query dengan dokumen kemudian dijumlahkan, setelah itu melakukan perkalian antara panjang dokumen dengan panjang query yang telah dikuadratkan, setelah itu di hitung akar pangkat dua. Selanjutnya hasil perkalian skalar tersebut di bagi dengan hasil perkalian panjang dokumen dan query.

Cosine similarity atau Kesamaan cosine adalah ukuran kesamaan antara dua vektor bukan- nol dari ruang produk dalam. Didefinisikan sama dengan cosinus sudut di antara mereka, yang juga sama dengan produk dalam dari vektor yang sama dinormalisasi untuk keduanya memiliki Panjang

\section{HASIL DAN PEMBAHASAN}

Hasil dan pembahasan pada rancang bangun ujian online menggunakan algoritma cosine similarity berbasis web, dimulai dari perancangan use case diagram.

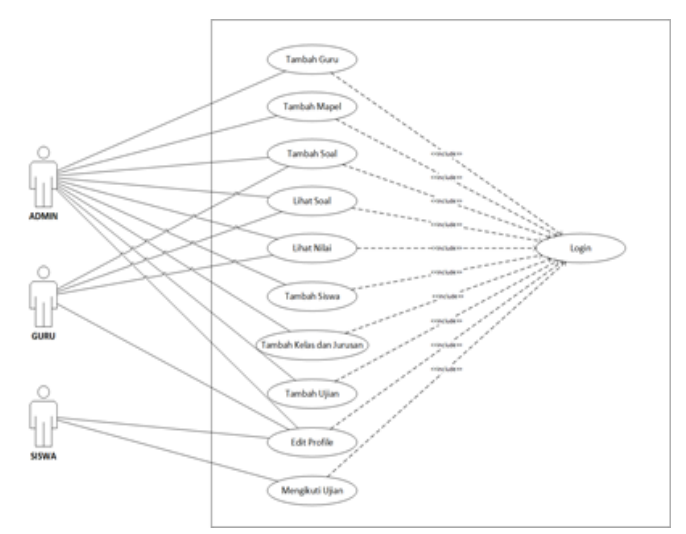

Gambar 1. Use Case Diagram Sistem Aplikasi Ujian Sekolah

Selanjutnya perancangan activity diagram yang menjelaskan bagaimana aliran kerja pada suatu sistem, pada sistem disini yaitu sistem ujian online. Ada beberapa activity yaitu Activity Diagram Admin Tambah Guru, Activity Diagram Admin Tambah Mapel, Activity Diagram Admin Tambah Soal, Activity Diagram Admin Lihat Soal Kelas, Activity Diagram Admin Lihat Nilai, Activity Diagram Admin Tambah Siswa, Activity Diagram Admin Tambah Kelas, Activity Diagram Admin Tambah Ujian, Activity Diagram Guru Tambah Soal, Activity Diagram Guru Lihat Soal, Activity Diagram Guru Lihat Nilai, Activity Diagram Murid Ikut Ujian, berikut gambar Activity Diagram Murid Ikut Ujian. 


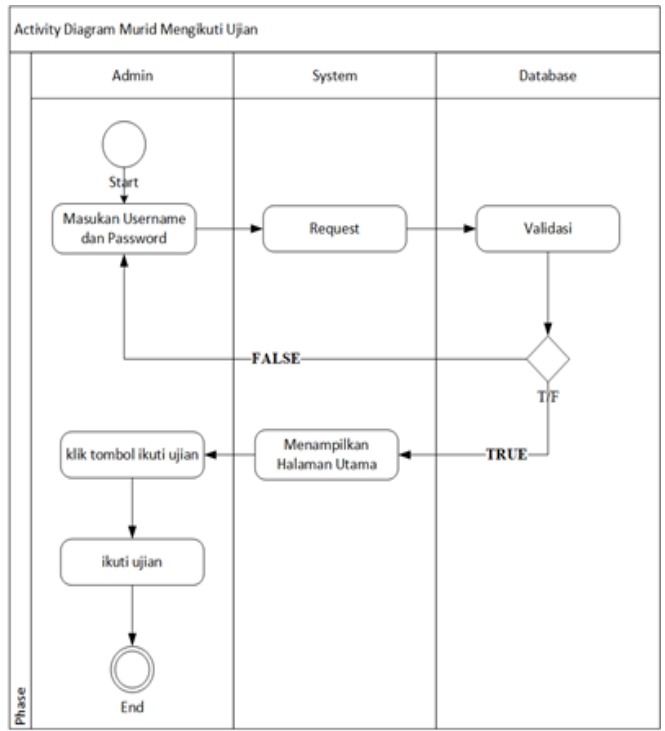

Gambar 2. Activity Diagram Murid Ikut Ujian

Pembahasan selanjutnya yaitu perancangan class diagram, berikut class diagram yang digunakan untuk membuat sistem aplikasi ujian sekolah.

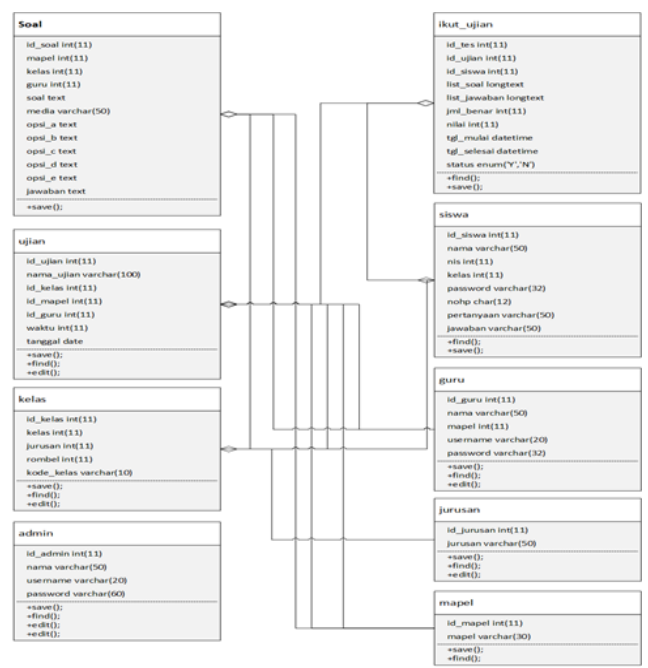

Gambar 3. Class Diagram Sistem Aplikasi Ujian Sekolah

Pemabahasan berikut nya tentang rancangan database, berikut relasi antar tabel yang digunakan.

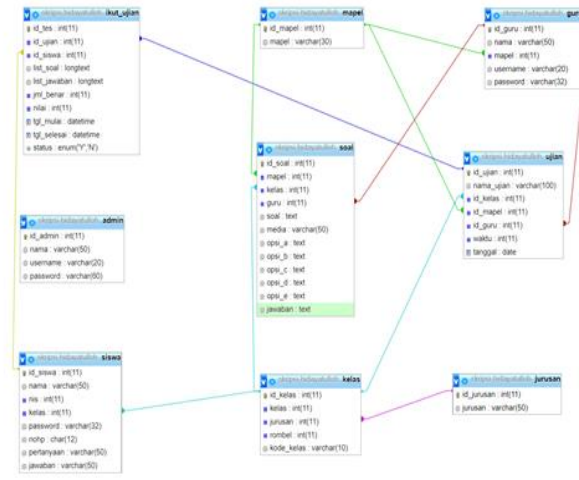

Gambar 4. Relasi antar tabel

Dari relasi antar tabel dapat di breakdown ada beberapa tabel yang digunakan yaitu Tabel kelas, tabel jurusan, tabel mapel, tabel siswa, tabel ujian, tabel ikut_ujian, tabel admin, tabel soal, dan tabel guru.

pada aplikasi ujian sekolah berbasis web ini terdiri dari 3 sub bagian yaitu aplikasi ujian sekolah untuk admin, aplikasi ujian sekolah untuk guru, dan aplikasi ujian sekolah untuk siswa. berikut tampilan halaman utama pada admin.

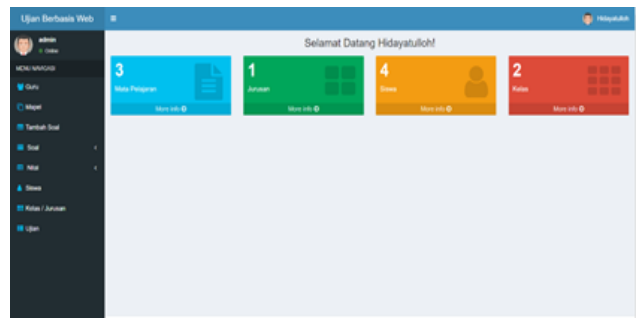

Gambar 5. Halaman utama untuk admin

Halaman utama pada guru, dapat menambahkan tambah soal, soal dan nilai, berikut tampilan halaman utama pada guru.

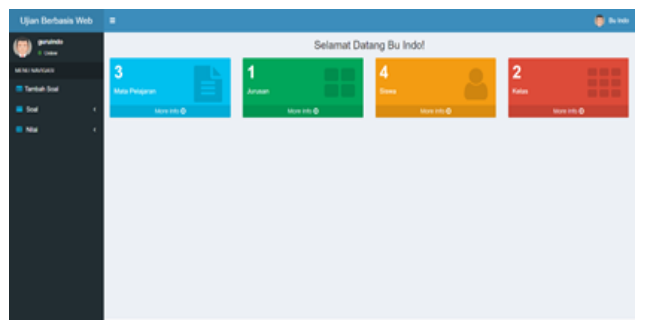

Gambar 6. Halaman utama untuk guru

Pada halaman siswa, siswa dapat melihat dashboard ujian berbasis web, beriktu 
tampilan nya.

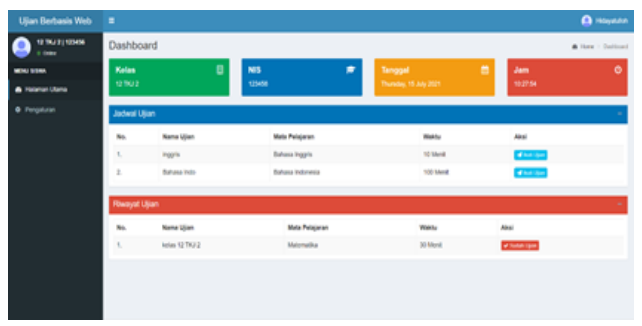

Gambar 7. Halaman utama untuk siswa

Pengujian pada Aplikasi Ujian Sekolah Berbasis Web dengan metode pengujian Black-Box. Pengujian ini dilakukan pada beberapa sistem yaitu Pengujian Black-Box Interface Sistem, Pengujian Black-Box Fungsi Dasar Sistem, Pengujian Black-Box Form Handle Sistem, Pengujian Black-Box Keamanan Sistem Aplikasi.

Pengujian fungsi interface sistem bertujuan untuk mengetahui fungsionalitas dari elemen-elemen interface yang terdapat di dalam halaman sistem. Elemen-elemen interface yang diujikan terutama adalah elemen-elemen button.

Tabel 1. Pengujian Black-Box Interface Sistem

\begin{tabular}{|c|c|c|c|c|}
\hline $\begin{array}{l}\mathbf{N} \\
\mathbf{0}\end{array}$ & $\begin{array}{c}\text { Test } \\
\text { Case }\end{array}$ & $\begin{array}{c}\text { Hasil } \\
\text { yang } \\
\text { dihara } \\
\text { pkan }\end{array}$ & $\begin{array}{c}\text { Hasil } \\
\text { yang } \\
\text { didapa } \\
\text { tkan }\end{array}$ & $\begin{array}{c}\text { Keter } \\
\text { anga } \\
\mathbf{n}\end{array}$ \\
\hline 1. & $\begin{array}{l}\text { Pengu } \\
\text { jian } \\
\text { button } \\
\text { Tamb } \\
\text { ah. }\end{array}$ & $\begin{array}{l}\text { Sistem } \\
\text { akan } \\
\text { mempr } \\
\text { oses } \\
\text { form. }\end{array}$ & $\begin{array}{l}\text { sistem } \\
\text { menjala } \\
\text { nkan } \\
\text { fungsi } \\
\text { proses } \\
\text { form }\end{array}$ & $\begin{array}{c}\text { Berha } \\
\text { sil. }\end{array}$ \\
\hline 2. & $\begin{array}{l}\text { Pengu } \\
\text { jian } \\
\text { button } \\
\text { Selesa } \\
i .\end{array}$ & $\begin{array}{l}\text { Sistem } \\
\text { akan } \\
\text { menyi } \\
\text { mpan } \\
\text { data } \\
\text { dan } \\
\text { keluar } \\
\text { dari } \\
\text { interfa } \\
\text { ce } \\
\text { form } \\
\text { dan } \\
\text { kemba } \\
\text { li ke } \\
\text { halama }\end{array}$ & $\begin{array}{l}\text { Sistem } \\
\text { penyim } \\
\text { pan } \\
\text { data } \\
\text { dan } \\
\text { kembal } \\
\text { i ke } \\
\text { halama } \\
\text { n } \\
\text { utama } \\
\text { modul } \\
\text { yang } \\
\text { bersang } \\
\text { kutan. }\end{array}$ & $\begin{array}{c}\text { Berha } \\
\text { sil. }\end{array}$ \\
\hline
\end{tabular}

\begin{tabular}{|c|c|c|c|c|}
\hline & & $\begin{array}{l}\mathrm{n} \\
\text { utama } \\
\text { modul } \\
\text { yang } \\
\text { bersan } \\
\text { gkutan }\end{array}$ & & \\
\hline 3. & $\begin{array}{l}\text { Pengu } \\
\text { jian } \\
\text { button } \\
\text { Edit. }\end{array}$ & $\begin{array}{l}\text { Sistem } \\
\text { akan } \\
\text { masuk } \\
\mathrm{ke} \\
\text { form } \\
\text { edit } \\
\text { data. }\end{array}$ & $\begin{array}{l}\text { Sistem } \\
\text { masuk } \\
\text { ke } \\
\text { halama } \\
\text { n yang } \\
\text { menyaj } \\
\text { ikan } \\
\text { Form } \\
\text { edit } \\
\text { data. }\end{array}$ & $\begin{array}{c}\text { Berha } \\
\text { sil. }\end{array}$ \\
\hline 4. & $\begin{array}{l}\text { Pengu } \\
\text { jian } \\
\text { Button } \\
\text { Hapus } \\
\text { - }\end{array}$ & $\begin{array}{l}\text { Sistem } \\
\text { akan } \\
\text { menjal } \\
\text { ankan } \\
\text { proses } \\
\text { pengha } \\
\text { pusan } \\
\text { data. }\end{array}$ & $\begin{array}{l}\text { Sistem } \\
\text { mengha } \\
\text { pus } \\
\text { data } \\
\text { yang } \\
\text { terpilih. }\end{array}$ & $\begin{array}{c}\text { Berha } \\
\text { sil. }\end{array}$ \\
\hline 5. & $\begin{array}{l}\text { Pengu } \\
\text { jian } \\
\text { Мепи }\end{array}$ & $\begin{array}{l}\text { Sistem } \\
\text { akan } \\
\text { masuk } \\
\text { ke } \\
\text { modul } \\
\text { yang } \\
\text { bersan } \\
\text { gkutan } \\
\text {. }\end{array}$ & $\begin{array}{l}\text { Sistem } \\
\text { masuk } \\
\text { ke } \\
\text { halama } \\
\text { n dari } \\
\text { modul } \\
\text { yang } \\
\text { dipilih } \\
\text { lewat } \\
\text { interfac } \\
\text { e menu. }\end{array}$ & $\begin{array}{c}\text { Berha } \\
\text { sil. }\end{array}$ \\
\hline
\end{tabular}

Pengujian fungsi dasar sistem aplikasi bertujuan untuk mengetahui kerja dari fungsi-fungsi dasar pada sistem.

Tabel 2. Pengujian Black-Box Fungsi Dasar

\begin{tabular}{|c|c|c|c|c|}
\hline $\begin{array}{l}\mathbf{N} \\
\mathbf{0}\end{array}$ & $\begin{array}{l}\text { Test } \\
\text { Case }\end{array}$ & $\begin{array}{l}\text { Hasil } \\
\text { yang } \\
\text { diharap } \\
\text { kan }\end{array}$ & $\begin{array}{l}\text { Hasil } \\
\text { yang } \\
\text { didapa } \\
\text { tkan }\end{array}$ & $\begin{array}{l}\text { Keter } \\
\text { anga } \\
\text { n }\end{array}$ \\
\hline 1. & $\begin{array}{l}\text { Pengu } \\
\text { jian } \\
\text { fungsi } \\
\text { tampil } \\
\text { an } \\
\text { data. }\end{array}$ & $\begin{array}{l}\text { Data } \\
\text { akan } \\
\text { ditampil } \\
\text { kan } \\
\text { sesuai } \\
\text { dengan } \\
\text { modul } \\
\text { yang }\end{array}$ & $\begin{array}{l}\text { Data } \\
\text { dapat } \\
\text { ditampi } \\
\text { lkan } \\
\text { dalam } \\
\text { format } \\
\text { datagri } \\
\text { d. }\end{array}$ & $\begin{array}{c}\text { Berha } \\
\text { sil. }\end{array}$ \\
\hline
\end{tabular}




\begin{tabular}{|c|c|c|c|c|}
\hline & & terpilih. & & \\
\hline 2. & $\begin{array}{l}\text { Pengu } \\
\text { jian } \\
\text { fungsi } \\
\text { tamba } \\
\text { h } \\
\text { data. }\end{array}$ & $\begin{array}{l}\begin{array}{l}\text { Data } \\
\text { akan } \\
\text { masuk }\end{array} \\
\text { ke } \\
\text { dalam } \\
\text { basis } \\
\text { data. }\end{array}$ & $\begin{array}{l}\text { Data } \\
\text { tersebut } \\
\text { dimasu } \\
\text { kan ke } \\
\text { dalam } \\
\text { basis } \\
\text { data. }\end{array}$ & $\begin{array}{c}\text { Berha } \\
\text { sil. }\end{array}$ \\
\hline 3. & $\begin{array}{l}\text { Pengu } \\
\text { jian } \\
\text { fungsi } \\
\text { ubah } \\
\text { data. }\end{array}$ & $\begin{array}{l}\text { Data } \\
\text { akan } \\
\text { berubah } \\
\text { sesuai } \\
\text { dengan } \\
\text { input } \\
\text { user. }\end{array}$ & $\begin{array}{l}\text { Data } \\
\text { beruba } \\
\mathrm{h} \\
\text { sesuai } \\
\text { dengan } \\
\text { input } \\
\text { user. }\end{array}$ & $\begin{array}{c}\text { Berha } \\
\text { sil. }\end{array}$ \\
\hline 4. & $\begin{array}{l}\text { Pengu } \\
\text { jian } \\
\text { fungsi } \\
\text { hapus } \\
\text { data. }\end{array}$ & $\begin{array}{l}\text { Data } \\
\text { yang } \\
\text { akan } \\
\text { dihapus } \\
\text { dari } \\
\text { basis } \\
\text { data. }\end{array}$ & $\begin{array}{l}\text { Data } \\
\text { yang } \\
\text { dipilih } \\
\text { terhapu } \\
\text { s. }\end{array}$ & $\begin{array}{c}\text { Berha } \\
\text { sil. }\end{array}$ \\
\hline
\end{tabular}

Pengajuan Form handle sistem aplikasi bertujuan untuk mengetahui kemampuan sistem untuk menangani bermacam-macam input yang diberikan oleh $u s e r$

Tabel 3. Pengujian Black-Box Form Handle Sistem

\begin{tabular}{|c|c|c|c|c|}
\hline $\begin{array}{l}\mathbf{N} \\
\mathbf{0}\end{array}$ & $\begin{array}{l}\text { Test } \\
\text { Case }\end{array}$ & $\begin{array}{l}\text { Hasil } \\
\text { yang } \\
\text { diharap } \\
\text { kan }\end{array}$ & $\begin{array}{l}\text { Hasil } \\
\text { yang } \\
\text { didapa } \\
\text { tkan }\end{array}$ & $\begin{array}{l}\text { Keter } \\
\text { anga } \\
\mathbf{n}\end{array}$ \\
\hline 1. & $\begin{array}{l}\text { Pengisi } \\
\text { an } \\
\text { Form } \\
\text { dengan } \\
\text { data } \\
\text { yang } \\
\text { benar. }\end{array}$ & $\begin{array}{l}\text { Sistem } \\
\text { akan } \\
\text { mempros } \\
\text { es form. }\end{array}$ & $\begin{array}{l}\text { Sistem } \\
\text { mempr } \\
\text { oses } \\
\text { input } \\
\text { form. }\end{array}$ & $\begin{array}{c}\text { Berha } \\
\text { sil. }\end{array}$ \\
\hline 2. & $\begin{array}{l}\text { Pengisi } \\
\text { an form } \\
\text { dengan } \\
\text { data } \\
\text { yang } \\
\text { salah } \\
\text { atau } \\
\text { menggu } \\
\text { nakan } \\
\text { symbol. }\end{array}$ & $\begin{array}{l}\text { Sistem } \\
\text { tidak } \\
\text { akan } \\
\text { mempros } \\
\text { es form } \\
\text { dan } \\
\text { memberi } \\
\text { kan } \\
\text { feedback } \\
\text { kepada } \\
\text { user. }\end{array}$ & $\begin{array}{l}\text { Halam } \\
\text { an } \\
\text { tidak } \\
\text { pindah } \\
\text { dan } \\
\text { muncul } \\
\text { pesan } \\
\text { terjadi } \\
\text { nya } \\
\text { kesalah } \\
\text { an } \\
\text { pada } \\
\text { field } \\
\text { yang }\end{array}$ & $\begin{array}{c}\text { Berha } \\
\text { sil. }\end{array}$ \\
\hline
\end{tabular}

\begin{tabular}{|c|c|c|c|c|}
\hline & & & $\begin{array}{l}\text { bersan } \\
\text { gkutan. }\end{array}$ & \\
\hline 3. & $\begin{array}{l}\text { Form } \\
\text { tidak di } \\
\text { isi lalu } \\
\text { di } \\
\text { simpan. }\end{array}$ & $\begin{array}{l}\text { Sistem } \\
\text { tidak } \\
\text { akan } \\
\text { mempros } \\
\text { es form } \\
\text { dan } \\
\text { memberi } \\
\text { kan } \\
\text { feedback } \\
\text { kepada } \\
\text { user. }\end{array}$ & $\begin{array}{l}\text { Halam } \\
\text { an } \\
\text { tidak } \\
\text { pindah } \\
\text { dan } \\
\text { muncul } \\
\text { pesan } \\
\text { terjadi } \\
\text { nya } \\
\text { kesalah } \\
\text { an } \\
\text { pada } \\
\text { field } \\
\text { yang } \\
\text { bersan } \\
\text { gkutan. }\end{array}$ & $\begin{array}{c}\text { Berha } \\
\text { sil. }\end{array}$ \\
\hline
\end{tabular}

Pengujian keamanan sistem aplikasi bertujuan untuk mengetahui aspek keamanan yang dimiliki oleh Aplikasi

Tabel 4. Pengujian Black-Box Keamanan Sistem Aplikasi

\begin{tabular}{|l|l|l|l|c|}
\hline $\begin{array}{l}\text { N } \\
\text { o }\end{array}$ & $\begin{array}{l}\text { Test } \\
\text { Case }\end{array}$ & $\begin{array}{l}\text { Hasil } \\
\text { yang } \\
\text { diharap } \\
\text { kan }\end{array}$ & $\begin{array}{l}\text { Hasil yang } \\
\text { didapatka } \\
\text { n }\end{array}$ & $\begin{array}{l}\text { Ket } \\
\text { era } \\
\text { nga } \\
\text { n }\end{array}$ \\
\hline & $\begin{array}{l}\text { User } \\
\text { tidak } \\
\text { melaku } \\
\text { kan } \\
\text { proses } \\
\text { login. }\end{array}$ & $\begin{array}{l}\text { User } \\
\text { tidak } \\
\text { akan } \\
\text { masuk } \\
\text { ke } \\
\text { dalam } \\
\text { sistem. }\end{array}$ & $\begin{array}{l}\text { Sistem } \\
\text { selalu } \\
\text { menampilk } \\
\text { an form } \\
\text { login. }\end{array}$ & $\begin{array}{c}\text { Ber } \\
\text { hasi } \\
1 .\end{array}$ \\
\hline $\begin{array}{l}\text { User } \\
\text { masuk } \\
\text { ke } \\
\text { halama } \\
\text { n yang } \\
\text { bukan } \\
\text { merupa }\end{array}$ & $\begin{array}{l}\text { User } \\
\text { tidak } \\
\text { akan } \\
\text { masuk } \\
\text { kan } \\
\text { haknya }\end{array}$ & $\begin{array}{l}\text { ke } \\
\text { halaman } \\
\text { sistem. }\end{array}$ & $\begin{array}{l}\text { Sistem } \\
\text { melakukan } \\
\text { redirect } \text { ke } \\
\text { halaman } \\
\text { login. }\end{array}$ & $\begin{array}{c}\text { Ber } \\
\text { hasi } \\
1 .\end{array}$ \\
\hline $\begin{array}{l}\text { Penguji } \\
\text { an } \\
\text { tampila } \\
\text { n menu } \\
\text { dengan } \\
\text { hak } \\
\text { akses } \\
\text { user. }\end{array}$ & $\begin{array}{l}\text { Menu } \\
\text { akan } \\
\text { muncul } \\
\text { sesuai } \\
\text { dengan } \\
\text { hak } \\
\text { akses } \\
\text { yang }\end{array}$ & $\begin{array}{l}\text { Menu yang } \\
\text { muncul } \\
\text { bervariasi, } \\
\text { sesuai } \\
\text { dengan hak } \\
\text { akses } \text { user } \\
\text { yang } \\
\text { bersangkut }\end{array}$ & $\begin{array}{l}\text { Ber } \\
\text { hasi } \\
1 .\end{array}$ \\
\hline
\end{tabular}




\begin{tabular}{|l|l|l|l|}
\hline & $\begin{array}{l}\text { dimiliki } \\
\text { oleh } \\
\text { user. }\end{array}$ & an. & \\
\hline
\end{tabular}

\section{KESIMPULAN}

berikut dapat di ambil dari analisis dan pengaturan sistem informasi Ujian sekolah, pengenalan sistem aplikasi ujian online berbasis web telah efektif dalam menyelesaikan permasalahan, Bagi guru, sistem hasil rancangan ini dapat mempermudah proses kegiatan Ujian online, untuk memudahkan mengelola nilai, dan dengan adanya sistem aplikasi ujian online ini dapat efisien dalam memberikan soal ujian, Bagi siswa, mempermudah siswa dalam melihat hasil ujian secara langsung.

\section{DAFTAR PUSTAKA}

[1] A. Hafiz et al., "Rancang Bangun Aplikasi Android Sebagai Media Pembelajaran Interaktif Berbasis Dua Dimensi Untuk Pembelajaran Di Taman Kanak-Kanak," J. Inf. dan Komput., vol. 9, no. 1, pp. 94100, 2021, doi: 10.35959/jik.v9i1.200.

[2] Z. M. Subekti, M. D. Suryadi, and R. Ardiansyah, "Aplikasi Layanan Administrasi Kependudukan Berbasis Web di Kelurahan Mangun Jaya," vol. 20, no. 68, pp. 139-147, 2021.

[3] W. M. Wijaya and Z. M. Subekti, “Jurnal Manajemen Pendidikan Penerapan Aplikasi Database pada Kegiatan Manajemen Sekolah The Use of Database Applications in School Management Activities," vol. 1, no. 2, pp. 157-166, 2019.

[4] Z. M. Subekti, "Implementasi Keamanan Akses Sharing Folder pada Windows 10," vol. 11, no. 1, 2021.

[5] Z. Mutaqin Subekti, "Optimasi Jaringan Wireless Lokal Area Network untuk Akses Finger Print," Syntax J. Inform., vol. 9, no. 2, pp. 63-78, 2020, doi: 10.35706/syji.v9i2.4059.
[6] A. I. Ramdhani, Z. M. Subekti, I. Husein, and E. Imrohatun, "Aplikasi Jasa Service AC ( Air Conditioner ) Pada CV Teknik Makmur," vol. 20, pp. 148-155, 2021.

[7] J. Computech, "IMPLEMENTASI SISTEM INFORMASI PAYROLL PADA SEKOLAH," vol. 15 , no. 1, pp. 3137, 2021.

[8] E. L. Amalia, A. J. Jumadi, I. A. Mashudi, and D. W. Wibowo, "Analisis Metode Cosine Similarity Pada Aplikasi Ujian Online Otomatis (Studi Kasus JTI POLINEMA)," J. Teknol. Inf. dan Ilmu Komput., vol. 8, no. 2, p. 343, 2021, doi: 10.25126/jtiik.2021824356.

[9] F. Rahimi and A. N. Asyikin, "Aplikasi Penilaian Ujian Essay Otomatis Menggunakan Metode Cosine Similarity," Poros Tek., vol. 7, no. 2, pp. 88-94, 2015, [Online]. Available:

http://ejurnal.poliban.ac.id/index.ph p/porosteknik/article/view/218.

[10] M. A. Salim and Y. Anistyasari, "Pengembangan Aplikasi Penilaian Ujian Essay Berbasis Online Menggunakan Algoritma Nazief Dan Adriani Dengan Metode Cosine Mohammad Agus Salim Yeni Anistyasari Abstrak," IT-Edu J. Inf. Technol. Educ., vol. 02, no. 1, pp. 126-135, 2017.

[11] H. Arfandy and I. A. Musdar, "Rancang Bangun Sistem Cerdas Pemberian Nilai Otomatis Untuk Ujian Essai Menggunakan Algoritma Cosine Similarity," Inspir. J. Teknol. Inf. dan Komun., vol. 10, no. 2, p. 123, 2020 , doi: 10.35585/inspir.v10i2.2580. 